\title{
Ovarian Development and Spawning Pattern of Neosalanx pseudotaihuensis Zhang in Xujiahe Reservoir, Hubei Province
}

\author{
WANG Weimin ${ }^{1} \quad$ AMARARATNE Yakupitiyage ${ }^{2}$ \\ (1: Fisheries College of Huazhong Agricultural University, Wuhan 430070, P, R. China; \\ 2: Agricultural $\hat{O}^{\circ}$ Aquatic Systems Program, Asian Institute of Technology, Thailand)
}

\begin{abstract}
Samples were collected monthly from Xujiahe Reservoir from April 1992 to May 1996 and the ovarian development and spawning pattern in Neosalanx pseudotaihuensis Zhang were described. A histological analysis of oocyte development in $N$. pseudotaihuensis shows that the fish spawns serially. A six-stage maturity scale, based on both external morphology and oocyte composition, was proposed to classify ovarian development in $N$. pseudotaihuensis. Monthly trends in stages in ovarian development with the size and maturity of ocytes indicate that spawning extended from March to May and peaked between mid-April and mid-May. Histology of ovarian shows that N. pseudotaihuensis produced clutches of eggs, which were released at intervals. Data on length-frequencies and gonads shows that $N$. pseudotaihuensis typically died in a few weeks after last spawning.
\end{abstract}

Key Words Neosalanx pseudotaihuensis, ovarian development, spawning pattern, Xujiahe Reservoir

It is crucial to accurately assess the gonadal maturity stage of a breeder if artificial insemination is to be successful. For many purposes, for example in determining the proportion of the stock that is mature, it is suffcient to note whether or not the fish is going to spawn, or has spawned in the recent spawning season, i.e. by classifying them as mature or immature. At other times it may be necessary to use a more detailed description of the state of maturity. For this purpose a series of numbered stages may be used, from the immature fish up to spent fish ${ }^{[1]}$. Icefish also have a complete gondal developing process from the immature to the spent although their life span is only one year. Based on the histological studies of ovarian development, Chen, et al. found that the development of oocyte of Neosalanx taihuensis was composed of six phases and classified ovary maturity into six stages ${ }^{[2]}$. They mentioned that the development of the oocyte in the ovary of the fish was non-synchronous and the histological structure showed the ovary returned to stage IV after spawning. The fish continued to develop quickly to mature and spawned again in the same reproductive season. The parent fish produced at least two batches of eggs during their reproductive period and died off soon after last-spawning ${ }^{[3,4]}$. Chen ${ }^{[5]}$ and Chen, et $a l^{[2]}$. found that there were two spawning stocks for $N$. taihuensis, spring spawning population

* Received 1998-09-24; Accepted 1999-01-21. WANG Weimin, male, born in 1959, associate professor. 
(from mid-February to mid-May) and autumn spawning population (from the beginning of September to mid-November), in Taihu Lake and Poyang Lake.

Neosalanx pseudotaihuensis is a one-year-lived fish inhabiting in the midstream and downstream of the Yangtze River, its tributaries and attached waters ${ }^{[6-8]}$. It constitutes a major proportion of icefish production and is an important commercial fish in Hubei Province ${ }^{[8]}$. This species had been introduced into lakes and reservoirs of Hubei and the vicinity provinces of from Xujiahe Reservoir. However, little is known about the overian development of this fish in Xujiahe Reservior $^{[8]}$. In this study histological protocol was used to investigate ovarian development and spawning pattern in order to provide information for the success of artificial insemination in N. pseuclotaihuensis.

\section{Methodology}

Sampling was carried out on the beginning of each month from April 1992 to May 1996 in Xujiahe Reservoir. The sampling device is a seine net consisting of two $40 \mathrm{~m}$ long wings with a 25 $\mathrm{mm}$ mesh and a 100 - $\mathrm{m}$-long packet with a $2 \mathrm{~mm}$ mesh, each of which has a depth of $10 \mathrm{~m}$. Twenty-one different sites were surveyed and eight of them were visited regularly. Samples were collected at depths ranging from 3-20 m. Specimens were classified and fixed after fishing. The twelve-months' samples (the whole life of the fish) between May 1995 and April 1996 were used for histological examination.

A sample of the unripe ovarian tissue was fixed in $10 \%$ buffered neutral formalin fixative. Ovaries containing postvitellogenic oocytes were preserved in Bouin's fixative. After embedding in paraffin, serial sections of 5-7 $\mu \mathrm{m}$ thickness were made. Slices were stained with Mayer's haematoxylin-eosin( $\mathrm{HE}$ ).

The standard length and weight of each fish were recorded with a precision of $1 \mathrm{~mm}$ and $0.01 \mathrm{~g}$. The sex of each fish was determined by secondary sexual characteristics or by examining their gonads under a dissecting microscope. Their gonads were removed and staged according to the criteria of Bagenal, et al ${ }^{[9]}$.

\section{Results}

\subsection{Maturity stages of the ovary}

Ovaries were assigned to six stages of development according to gross morphological characteristics and oocyte composition (Table 1). Gross changes in the external appearance of ovary accompanied the appearance of yolk vesicle oocytes with vecortical alveoli, vitellogenic oocytes and maturation phase oocytes. However, histological examination was needed to distinguish partially spent ovaries from mature ovaries in order to detect the presence of post-ovulatory follicles.

\subsection{Stage of oocyte development}

The terminology used for staging the individual oocytes based on their histological appearance was taken from Bagenal ${ }^{[1]}$. 
Tab. 1 The classification of maturity stages in N.pseudotaihuensis

\begin{tabular}{|c|c|c|c|}
\hline & Maturity stage & External appearance & Cytological characteristics \\
\hline I & Immature & Ovaries very small, invisible to the naked eye & Perinucleolar stage oocytes predominant \\
\hline II & Development & $\begin{array}{l}\text { Ovaries translucent, slender. Eggs not distin- } \\
\text { guishable to the naked eye. }\end{array}$ & $\begin{array}{l}\text { Oocytes surrounded by a flattered follicular } \\
\text { layer. }\end{array}$ \\
\hline III & Mature & $\begin{array}{l}\text { Ovaries opaque, white. Occupying about } 20 \% \\
\text { of free body cavity. Eggs invisible to the naked } \\
\text { eye but visible with magnifying glass. }\end{array}$ & $\begin{array}{l}\text { Vitellogenic oocytes surrounded by two follicu- } \\
\text { lar layers. }\end{array}$ \\
\hline IV & Ripe & $\begin{array}{l}\text { Ovaries filling ventral cavity. Eggs completely } \\
\text { round. Single eggs can be seen from the out- } \\
\text { side of the abdomen but not so clear. }\end{array}$ & $\begin{array}{l}\text { Yolk granules densely packing and occupying } \\
\text { almost the total volume of the cocyte. }\end{array}$ \\
\hline V & Spawning & $\begin{array}{l}\text { Ovaries completely filling the free body cavity. } \\
\text { Egg clearly discernible from the outside of the } \\
\text { belly. Roe running with slight pressure. Most } \\
\text { eggs translucent. }\end{array}$ & $\begin{array}{l}\text { Oocytes containing post-ovulatory follicles pre- } \\
\text { dominate. }\end{array}$ \\
\hline VI & Spent & $\begin{array}{l}\text { Gonads containing a few left-over eggs. A few } \\
\text { eggs in the state of reabsorption. }\end{array}$ & Various oocytes present. \\
\hline
\end{tabular}

N. pseudotaihuensis have just one year life span. Most of them are born in April and die next April. Twelve months of gonad specimens were made for histological section from May 1995 (at the age of 1 month) to April 1996 (at the age of 12 months). Stages of oocyte development, therefore, were described for their lifetime (one year).

2.2.1 Stage I The dominant gametogenic cells were oogonia. Oogonia were very small, having a very dense and compact consistency. The diameter was $7-25 \mu \mathrm{m}$. They were present at the age of 1 to 3 months from May to July in Xujiahe Reservoir(Plate I, 1-3).

2.2.2 Stage II Due to a continuous increase of the cytoplasm and nuclear diameter, the cell had increased in diameter. A flattened follicular layer surrounding the oocytes could be distinguished at the end of this stage, which is the last one of the first growth phase. It was characterized by a nucleus containing many nucleoli and a cytoplasm that had become basophilic. It occurred from August until October at the age of 4 to 6 months (Plate I, 4-6).

2.2.3 Stage III Whitish cytoplasmic zones appeared in this first stage of the secondary growth phase, situated at the periphery of the oocyte, which probably correspond to the incipient formation of the cortical alveoli. Two follicular layers were present. Exogenous vitellogensis started with deposition of acidophilic yolk granules at the periphery of the oocyte. This stage occurred from November to next January at the age of 7 to 9 months (Plate I, 7-9)

2.2.4 Stage IV The appearance of oocytes was similar to that in stage III. The number of yolk granules was still increasing. They were densely packed and occupied almost the total volume of the oocyte. The nucleus started to migrate towards the periphery of the oocyte and contained 
more than 100 nucleoli at the later period of this stage. From the inner side of the oocyte to the outer the following layers were noted: the follicle cells, the zona radiata and the internal theca. The occurrence of this stage was in February at the age of 10 months (Plate I, 10).

2.2.5 Stage $V$ The envelope layers were clearly observed at this stage, and the zona radiata was greatly enlarged, the theca interna had small blood vessels to each oocyte. The vitellogenic granules were fused forming amorphous plaques of larger size; the yolk was dispersed. The nucleus, where evident, was no longer central, but had migrated to pole. This stage was found in March at the age of 11 month (Plate I, 11).

2.2.6 Stage VI The lamellage was disrupted and disorganized, with several empty spaces that were formerly occupied by ripe oocytes. Follicular cells, remnants of post-ovulatory follicles, were present throughout the gonad. Oocytes in stage 4 dominated, and oogonium and chromatin nucleus stage oocytes proliferated. Viteliogenic oocytes could be observed (Plate I, 12)

The occurrence of the different stages of oocyte development with their specific cell and nuclear diameters was summarized in Table 2 .

Tab.2 The stage of oocyte development in the ovary of N. pseudotaihuensiss

\begin{tabular}{|c|c|c|c|c|}
\hline $\begin{array}{c}\text { Stage of } \\
\text { development }\end{array}$ & $\begin{array}{c}\text { Cell diameter } \\
/ \mu \mathrm{m}\end{array}$ & $\begin{array}{c}\text { Nuclear diameter } \\
\text { / } / \mathrm{m}\end{array}$ & $\begin{array}{l}\text { Month } \\
\text { occurring }\end{array}$ & $\begin{array}{c}\text { Age occurring } \\
/ \text { month }\end{array}$ \\
\hline I & $7-25$ & $3-5$ & May - Jul. & $1-3$ \\
\hline II & $30-91$ & $6-17$ & Aug. - Oct. & $4-6$ \\
\hline III & $46-178$ & $24-43$ & Nov. - Jan. & $7-9$ \\
\hline $\mathrm{N}$ & $152-480$ & $59-113$ & Feb. - Mar. & 10 \\
\hline $\mathrm{V}$ & $474-609$ & Unclear & Mar. - Apr. & 11 \\
\hline V & Variety & Variety & Apr. - May & 12 \\
\hline
\end{tabular}

\subsection{Spawning age structure}

Length-frequency histograms for $N$. pseudotaihuensis in June 1993 showed two discrete size groups, the first raning from 22.4 to $45.8 \mathrm{~mm}$ and second from 51.2 to $73.6 \mathrm{~mm}$, and July 1993 had single group, raning from 32.7 to $48.8 \mathrm{~mm}$ (Fig. 1). Since the small fish were not present in samples prior to April, and as spawning occurs from March to May, these fish are assumed to represent new 0 recruits. Therefore, the spawning age structure of $N$. pseudotaihuensis is simple, and only one-year-old fish (supplementary population) and no remainder population attend reproduction.

\section{Discussion}

\subsection{Spawning period of $N$. pseudotaihuensis}

It is an important step in aquaculture to accurately assess the gonad maturity stage of a breeder, especially that of females at the artificial insemination of fishes ${ }^{[9]}$. A record of the state of maturity of icefish is required for artificial insemination in determining the proportion of the stock 

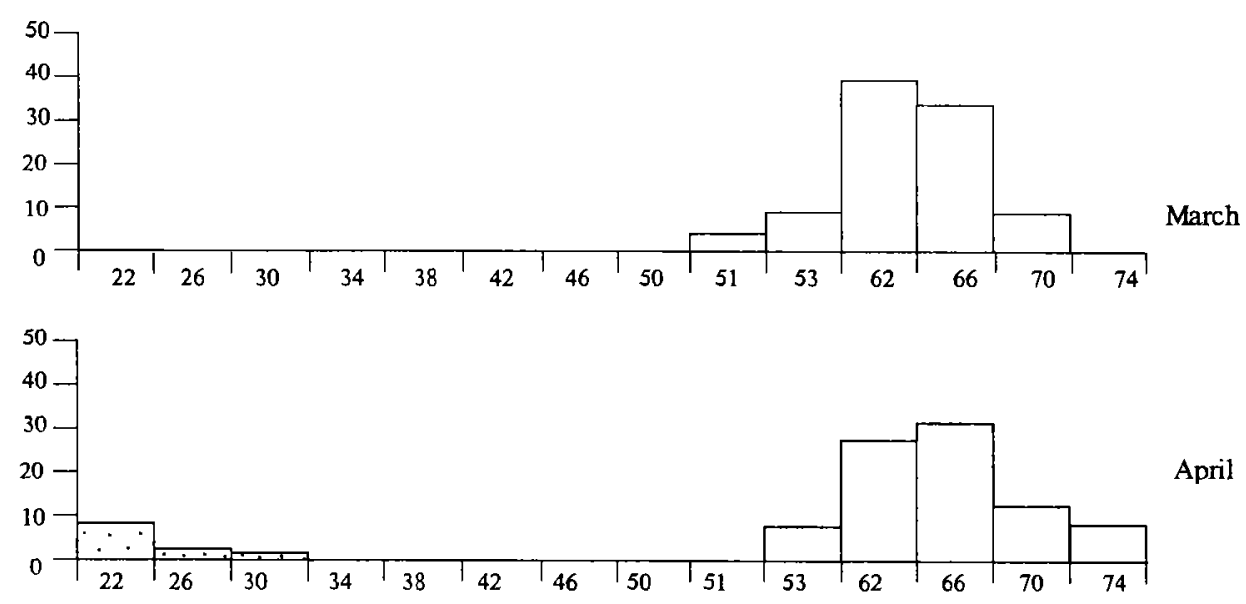

April

方

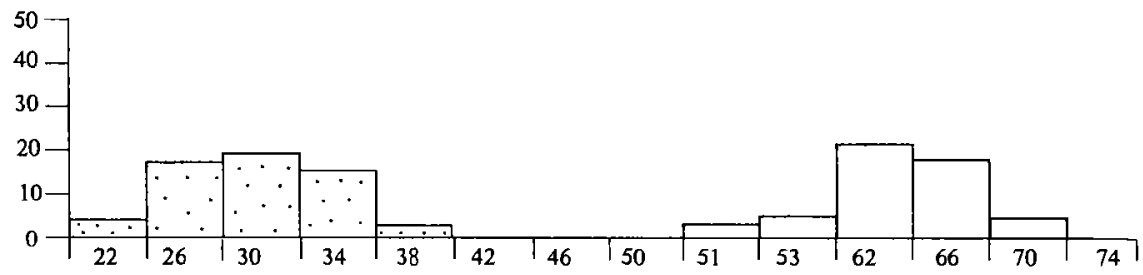

May

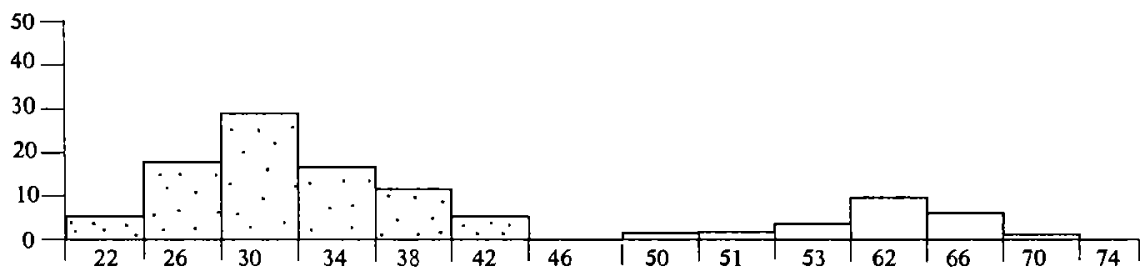

June

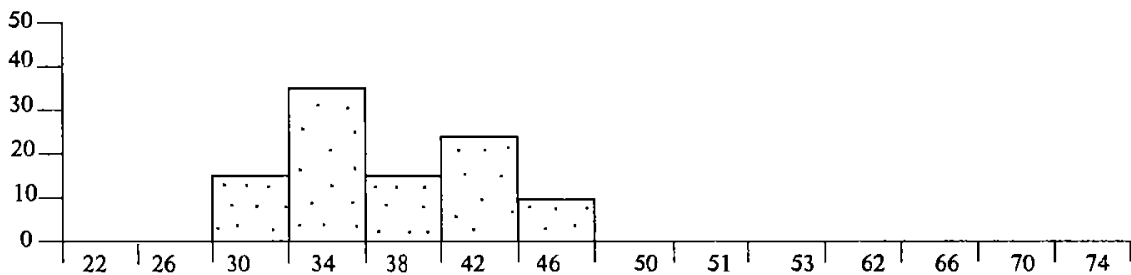

July

Fig. 1 Length-frequency histograms for the 1993, $\square$ and 1994, $\square$ year generations of N. pseudotaihuensis sampled between March and July, 1994

that is mature. It is sufficient to note whether or not the fish is going to spawn or has spawned in the recent spawning season. This would be particularly important to artificial insemination of icefish since the breeders are selected directly from the capture during the spawning season. They cannot be induced using hormone because they are very small-sized and perishable. A great quan- 
tity of well-matured spawners can only be captured during the peak period of spawning.

The fact that, in September and October 1995, none of the fish exceeded stage III of ovaries before January, demonstrated that $N$. pseudotaihuensis undergoes little gonadal development in the autumn and early winter. However, the marked increase that occurred in oocyte diameters and the stage in ovarian development during February, March and April, showed that the gonads mature rapidly between late winter and early spring.

The most common practice for the determination of a species spawning season is the establishment of its gonadosomatic index, oocyte diameter-frequency, and also being combined with microscopic and histological examination of the gonads ${ }^{[0]}$. The microscopic examination and histological secton of gonads can administer the maturity stages of gonad. The data on the monthly trends exhibited by gonadal stages and histological section of gonads provided strong evidence that $N$. pseudotaihuensis spawned between March and May, with spawning activity peaking in between mid-April and mid-May. This agrees with the findings of Chen, et al. who studied on $N$. taihuensis in Poyang $\mathrm{Lake}^{[2]}$. The sequence of histologically assigned developmental stages matched the trend in oocyte diameter frequency. From March to April, most gonads were "resting", and the developing gonads were at the highest stage.

\subsection{Spawning pattern of $N$. pseudotaihuensis}

The presence in stage VI ovaries of oocytes that intermediated in size between those of the small basophilic oocytes and the large yolk granule oocytes found in the same gonads, implied that $N$. pseudotaihuensis could be a multiple spawner, as had previously been shown by Chen, et al . for $N$. taihuensis. They reported that the histological structure of the ovary of $N$. taihuensis returned to stage $\mathrm{N}$ after spawning, the fish continued developing quickly to mature and spawning again in the same reproductive season. The same results were made to show that $N$. pseudotaihuensis produced more than one batch of eggs in the present study, as mature and ripe ovaries contained more than one distinct group or batch of oocytes and a continuous developmental serial of primary growth phase oocytes.

Tab.3 The annual changes of GSIs of $N$. pseudotaihuensis in Xujiahe Reservoir

\begin{tabular}{ccccccccccccc}
\hline Date & May & Jun & Jul & Aug & Sep & Oct & Nov . & Dec & Jan & Feb & Mar & Apr \\
\hline Age/month & 1 & 2 & 3 & 4 & 5 & 6 & 7 & 8 & 9 & 10 & 11 & 12 \\
GSI/\% & CM & CM & CM & CM & 0.64 & 0.98 & 1.95 & 2.17 & 4.16 & 8.18 & 11.97 & 18.40 \\
BW/mm & 20.6 & 30.8 & 36.7 & 41.8 & 46.5 & 50.7 & 54.6 & 56.8 & 58.6 & 60.3 & 61.1 & 61.4 \\
SM & 51 & 48 & 36 & 30 & 43 & 62 & 59 & 37 & 28 & 34 & 54 & 50 \\
\hline
\end{tabular}

M : Month; CM : Cannot be measured; BW : body weight ; SM : sample numbers

\subsection{Spawning population structure}

Chen and Chen et al found that there were two spawning stocks for $N$. taihuensis, spring spawning population (from mid-February to mid-May) and autumn spawning population (from the beginning of September to mid-November), in Taihu Lake and Poyang Lake ${ }^{[5,2]}$. From Table 3 , it showed that there was only one spawning stock, spring spawning population, for $N$. 
pseudotaihuensis in Xujiahe Reservoir. This is also true by means of checking population composition of N. pseudotaihuensis during the fishing season, autumn in Xujiahe Rservoir.

\section{Acknowledgments}

The author is indebted to the Royal Netherlands Government, Danida-AIT Student Research Program (Denmark) and Asian Institute of Technology (AIT) Alumni Association for providing research fund. Grateful acknowledgments are given to Dr. A. Yakupitiyage, Prof. C. Kwei Lin and Dr. D.C. Little in AIT for his support, encouragement and advice. Heartfelt thanks are extended to the leader of Guangshui City Fisheries Office and Xujiahe Reservoir Fisheries Branch Office, LIU Xingguo and his colleagues for offering a research site, supplementary research fund, assistance during the conduct of the study. This study would have been impossible without all their help. The author is very much grateful to the leaders and stuff of Fisheries College, Huazhong Agricultural University for providing equipment and assistance during the experiments. Sincere thanks to Prof. XIE Congxin, Mr. WEI Kaijian and their collaborator for help with histological studies.

\section{References}

1 Bagenal T B. Aspects of fish fecundity. In: Gerking S D ed. Ecology of freshwater fish production. Oxford: Blackwell Scientific Publications, 1978. $75-101$

2 Chen G H, B Zhang. Histological studies on the ovarian development of Neosalanx tangkaheii taihuensis in Poyang Lake. Journal of Zhangjiang College of Fisheries, 1990, 9(2):103-112(in Chinese with English abstract)

3 Sun G Y. Study on Salangidne of the Yangtze River Delta and its adjacent waters. Journal of East China Normal University, 1982, $1: 111$ - 119(in Chinese with English abstract)

4 Zhang K X. On the multiplication of Salangidae in Taihu Lake. Freshwater Fisheries, 1985, 2:2-7(in Chinese)

5 Chen N S. Primary study on Neosalanx tangkaheii taihuensis Chen. Acta Hydrologica Sinica, 1956, 2:324-334(in Chinese with English abstract)

6 Zhang Y L. A taxonomic study on the Chinese icefishes of genus Neosalanx (Pisces: Salangidae) with description of a new species from the Taihu Lake. Zoological Research, 1987, 8:272-286(in Chinese with English abstract).

7 Gong S Y, X P Zhang, S Q He. On the biology of Neosalanx pseudotaihuensis and its way of multiplication in Yuni Lake. Acta Hydrobiologica Sinica, 1995, 19:354-359 (in Chinese with English abstract).

8 Wang W M, G R Yang. Growth characteristics of Neosalanx pseudotaihuensis landlocked in Xujiahe Reservoir. Journal of Fisheries of China, 1996, 18:18-24 (in Chinese with English abstract).

9 Bagenal T B, E Braum. Eggs and early life history. In: Ricker W E ed. Methods for assessment of fish production in fresh waters. Oxford: Blackwell Scientific Publications, 1971. $166-189$

10 Pen L J, H S Giu, P Humphries, et al. Biology of the black stripe minnow Galaxiella nigrostratu, including comparisons with the other Galaxiella species. Mexico. Journal of Fish Biology, 1993, 43:847-863

\section{Captions to Plate I}

Histological appearance of developmental stages of occytes for a life of $N$. pseudotaihuensis. The time of sampling, magnification, and female age are indicated.

1: stage I (May 1995, 40×3.3, 1 month); 2 :stage I (June 1995, 40×3.3, 2 months); 3 :stage I (July 1995, 40 × 3.3, 3 months); 4 : stage II (August 1995, 40×3.3,4 months); $5:$ stage II (September 1995, $20 \times$ 
3.3, 5 months); 6 stage II (October 1995, $20 \times 3.3,6$ months); 7: stage III (November 1995, $10 \times 3.3,7$ months); 8 stage III (December 1995, $10 \times 3.3,8$ months); 9 :stage III (January 1996, 10×3.3. 9 months); 10 : stage IV (February 1996, 10×3.3, 10 months); 11:stage V (March 1996, $10 \times 3.3,11$ months); 12 :stage VI (April 1996, $10 \times 3.3,12$ months).

\title{
徐家河水库近太湖新银鱼 (Neosalanx pseudotaihuensis Zhang) 的性腺发育与产卵类型”
}

\author{
$I$ 民 $^{1} \quad$ AMARARATNE Yakupitiyage ${ }^{2}$ \\ (1:华和农业大学水产学院, 武汉 430070;
}

2: Agricultural \& Aquatic Systems Program, Asian Institute of Technology, Thailand)

摘 要 银鱼生产的发展是通过银鱼的引种来实现的, 银鱼的引种主要是采取向水体投放受精卵的 方式来完成。受精卵又是通讨人工繁殖而获得. 银鱼的人工繁殖不同于常规养殖鱼类, 因其一经捕起很快就公 死亡而不能进行人工催产. 因此银鱼人工繁殖的亲本是在银鱼的繁殖季节从天然水体中捕㭶而获得,而大望 的性成熟好的、可以立即进行人工受精的亲本只能在产卵高峰期才能捕获得到. 所以丁解并学握银鱼的性腺 发育规律和产卵时期对银鱼的人工繁殖十分重要.

1992 年 4 月至 1996 年 5 月在湖北省徐家河水库对近太湖新银鱼的性腺发育规律和产卵时期进行丁长 期的研究, 并从 1995 年 5 月至 1996 年 4 月 (银鱼的一生)周年标本中逐月进行了组织切片. 通过对近太湖新 银鱼 (Neosalanx pseudotaihuensis) 卵细胞的组织学研究表明该鱼为分批产卵类型. 根据卵巢外部形态利内部 组织结构, 建议将近太湖新银鱼的卵巢划分为六个阶段; 从卵巢每月发育期趋势和卵细胞大小以及卵的成热 度得出近太湖新银鱼的产卵期为 3-5 月, 其中 4月中旬至 5月中旬为产卵高峰期; 根据体长频率分布来看, 近太湖新银鱼产完最后一批卵就死亡, 因此, 它的寿命仅一年. 从其周年体长和成熟系数分布并结合秋季大捕

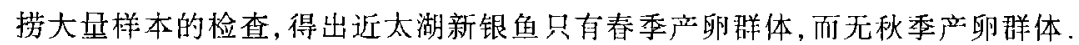

关键词近太湖新银鱼 性腺发育 产卵类型 徐家河水库

分类号 Q959.4

\section{图版说明(图版 I)}

近太湖新银鱼 (N. pseudotaihuensis Zhang) 卵母细胞发育的不同时期 (采样时间、放大倍数及月龄).

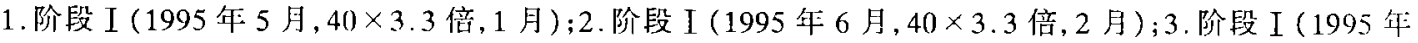
7 月, $40 \times 3.3$ 倍, 3 月 ); 4 . 阶段 II (1995 年 8 月, $40 \times 3.3$ 倍，4 月 ); 5 . 阶段 II (1995 年 9 月, $20 \times 3.3$ 倍, 5 月);

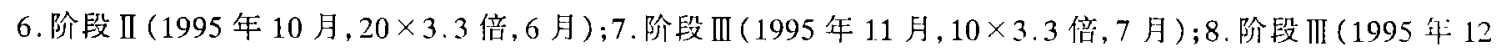
月, $10 \times 3.3$ 倍, 8 月)；9. 阶段 III (1996 年 1 月, $9 \times 3.3$ 倍, 10月); 10 . 阶段 $\mathrm{V}(1996$ 年 2 月, $10 \times 3.3$ 倍, 10 月); 11 、阶段 $V(1996$ 年 3 月, $10 \times 3.3$ 倍, 11 月)；12. 阶段 V(1996 年 4 月, $10 \times 3.3$ 倍, 12 月).

*收稿日期: 1998-09-24; 收到修改稿日期: 1999-01-21. 王卫民, 男, 1959 年生, 副教授. 